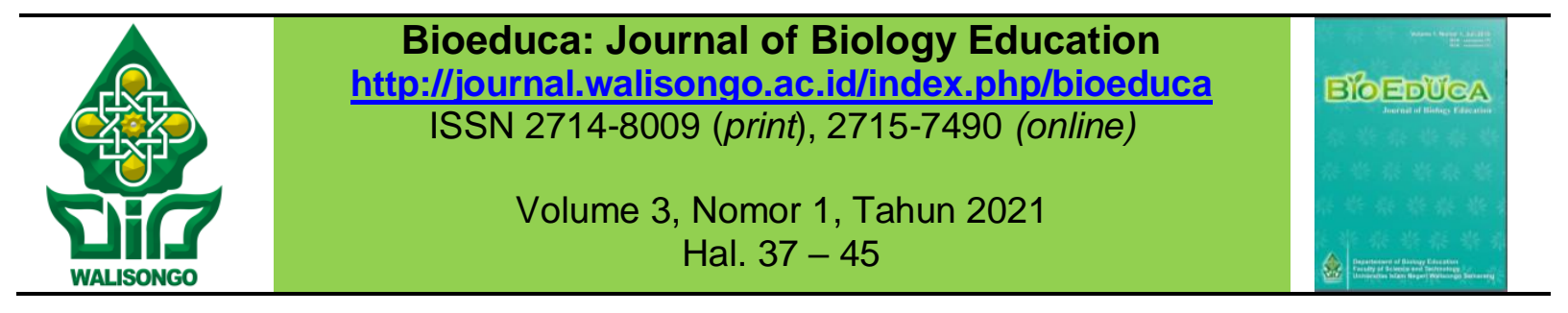

\title{
Pengembangan LKPD Materi Arthropoda Berbasis STEM Berteknologi Augmented Reality
}

\author{
Meyninda Destiara ${ }^{1 *}$, Nurul Himmah ${ }^{2}$, Sari Indriyani ${ }^{3}$ \\ 1,2,3Tadris Biologi, Universitas Islam Negeri Antasari Banjarmasin \\ *Email: meyninda.destiara@uin-antasari.ac.id
}

\begin{tabular}{ll}
\hline Informasi Artikel & \multicolumn{1}{c}{ ABSTRAK } \\
\hline Submit: $19-10-2020$ & LKPD merupakan bahan ajar yang terstruktur, dengan bantuan \\
Diterima: $29-03-2021$ & LKPD tersebut maka dapat membuat pembelajaran lebih aktif \\
Dipublikasikan: $31-03-2021$ & dan berfikir kreatif. Ditambah lagi LKPD yang dibuat berbasis \\
& STEM dan bantuan teknologi Augmented Reality yang inovatif, \\
& sehingga pembelajran daring menjadi interaktif. Penelitian ini \\
& bertujuan untuk mengembangkan LKPD Arthropoda berbasis \\
& STEM berteknologi Augmented Reality yang valid. Metode yang \\
& digunakan yaitu pengembangan dengan model ADDIE yang \\
& telah dimodifikasi sampai tahap development. Berdasarkan hasil \\
& validasi didapatkan LKPD dengan hasil valid dan layak untuk \\
& digunakan. \\
& Kata kunci: augmented reality; LKPD; STEM. \\
\hline Penerbit & \multicolumn{1}{c}{ ABSTRACT } \\
\hline Program Studi Pendidikan & Student worksheets are structured teaching materials, with the \\
Biologi, Fakultas Sains dan & help of these student worksheets it can make learning more \\
Teknologi, UIN Walisongo & active and think creatively. Besides, student worksheets are \\
Semarang & made based on STEM and the help of innovative Augmented \\
& Reality technology, so that online learning becomes interactive. \\
& This study aims to develop valid STEM-based Arthropoda student \\
& worksheets with Augmented Reality technology. The method \\
& used is development with the ADDIE model that has been \\
& modified until the development stage. Based on the results of the \\
validation, it was found that student worksheets were valid and & \\
suitable for use. & \\
Keywords: augmented reality; STEM; worksheet.
\end{tabular}

Copyright (C2021, Bioeduca: Journal of Biology Education

\section{PENDAHULUAN}

Arthropoda merupakan hewan seranggga yang memiliki ciri berbuku-buku atau tubuh yang beruas-ruas. Arthropoda dibahas secara terinci pada bab Animalia kelas $X$ di Sekolah Menengah Atas atau SMA, yang terlihat jelas pada sajian silabus mengenai sajian materi arthropoda tersebut membahas secara umum jenis-jenis arthopoda berdasarkan ciri-ciri morfologi berdasarkan filumnya.

Sesuai dengan kurikulum 2013, pembelajaran bersumber pada murid untuk melakukan eksperimen atau pengamatan ilmiah. Permendikbud No.65 tahun 2013 tentang standar proses pendidikan dasar dan mengengah juga mengisyaratkan bahwa perlunya proses pembelajaran yang dipandu dengan kaidah-kaidah pendekatan 
saintifik atau ilmiah. Sehingga guru dituntut kreatif dalam melaksanakan pembelajaran di kelas agar tujuan dari kompetisi dasar tercapai. Hal ini sejalan dengan perkembangan dunia pendidikan yang meintegrasikan lebih dari satu disiplin ilmu yaitu STEM (Science, teknologi, engeneering and mathematics).

STEM merupakan pembelajaran praktik yang mengintegrasikan antara ilmu pengetahuan, teknologi, teknik dan matematika yang berfokus pada pendidikan (Mulyani, 2019). Pendekatan STEM tersebut secara tidak langsung dapat membuat guru dan siswa untuk berfikir kreatif dan aktif serta beriinovatif dalam kegiatan pembelajaran.

Berdasarkan hasil observasi di SMAN 7 Banjarmasin, pada saat pembelajaran biologi berlangsung, siswa diarahkan untuk melakukan pengamatan ilmiah dengan LKPD yang disediakan oleh guru. LKPD atau Lembar kerja peserta didik merupakan bahan ajar cetak berupa lembar-lembar kertas yang berisi materi, ringkasan dan petunjuk-petunjuk pelaksanaan tugas dengan mengacu kepada kompetensi dasar (KD) yang harus dicapai (Prastowo, 2015). LKPD yang diberikan guru menugaskan siswa untuk melakukan pengamatan langsung objek-objek dengan membawa spesies atau jenis hewan tersebut secara langsung kedalam kelas.

Sesuai capaian KD pada LKPD tersebut, siswa membawa hewan-hewan saat tema pengamatan artropoda, yaitu seperti semut, lebah, kelabang, kalajengking, udang, kaki seribu, laba-laba dan berbagai jenis arthopoda. Namun, ketika pengamatan siswa terkendala menyentuh spesies tersebut karena takut tersengat karena sebagian hewannya memiliki racun. Maka sebab itu pengamatan hanya terbatas melihat secara jarak jauh dari objek yang diamati.

Meskipun pengamatan hanya melihat dari jarak jauh tidak sampai menyentuh, siswa terlihat sangat antusias karena melihat objek secara langsung (pengamatan secara langsung). Sesuai menurut Widjajanti (2008) fungsi LKPD yaitu dapat meningkatkan minat siswa dalam belajar dan dapat mudah dipahami siswa sehingga menarik perhatian ketika menggunakan.

Berdasarkan paparan tersebut menjadi dasar pijakan untuk mengembangkan sebuah LKPD inovatif, yaitu LKPD berbantuan teknologi Augmented Reality. Augmented reality yaitu teknologi yang dapat memvisualkan benda 2 dimensi menjadi 3 dimensi sehingga dapat terlihat real. Sesuai menurut Destiara \& Hermawan (2020) bahwa teknologi Augmented Reality dapat membantu dalam proses pembelajaran biologi. Oleh sebab itu dengan bantuan teknologi tersebut dapat membantu menjangkau hal yang masih belum bisa dilakukan pada saat pengamatan, seperti halnya pengamatan pada objek-objek yang memiliki racun atau bisa.

Berdasarkan hasil analisis kebutuhan yang dilksanakan dengan siswa di SMAN 7 Banjarmasin, didapatkan hasil bahwa semua siswa memiliki gawai berbasis android. Namun gawai belum dimanfaatkan lebih lanjut untuk aplikasi pendukung LKPD sebagai media pengamatan. Kebanyakan dari mereka memanfaatkan smartpone atau gawai sebagai sarana mencari informasi dan hiburan sosial media.

Sesuai menurut Kitchenham (2011) berpendapat bahwa pemanfaatan Smartphone dalam pendidikan dapat menjadikan alternatif dalam pengembangan 
media belajar. Selain itu Laurillard (2007) mengemukakan bahwa dengan smarhpone dalam pendidikan membuat teknologi ini berperan utama untuk menjadi sarana penyampaian informasi kepada siswa melalui teknologi perangkat handpone tersebut. Sehingga sesuai dengan pendapat tersebut menjadi pijakan peneliti dalam mengembangkan sebuah LKPD dengan bantuan media seperti smartphone yang dapat digunakan dengan mudah oleh siswa.

Sesuai risert-riset sebelumnya, pengembangan teknologi sebagai media pembelajaran sangat mengalami peningkatan yang pesat dalam dunia pendidikan. Seperti riset yang dilaksanakan oleh Asri (2019) memanfaatkan Smartphone sebagai media pembelajaran mata pata kuliah koreografi dan komposisi tari I dan yang dilaksanakan oleh Suhendra (2020) dengan memanfaatkan smartphone sebagai media pembelajaran berbasis daring pada masa covid-19 di MI Ma'arif 07 Karangmangu Kecamatan Kroya Kabupaten Cilacap. Sehingga dari riset tersebut terlihat bahwa fungsi smartphone selain untuk komunikasi smartphone juga dapat menunjang dalam proses pembelajaran.

Dewasa ini pembelajaran jarak jauh menjadi himbauan utama oleh menteri pendidikan yang harus dilaksanakan, Sesuai edaran Kemendikbud (2020) yang berisikan edaran dengan melaksanakan belajar dari rumah dalam masa darurat penyebaran Covid-19. Berdasarkan hal tersebut menjadi tantangan besar bagi dunia pendidikan untuk beradaptasi dengan melaksanakan pembelajaran jarak jauh. Sehingga dari hal ini guru dituntut untuk berinovasi dalam mengajar secara daring atau dalam jaringan.

Berdasarkan paparan tersebut, bahwa teknologi merupakan solusi untuk melakukan pembelajaran jarak jauh, dengan memanfaatkan media-media yang ada atau mengembangkan media yang terbaharukan merupakan jembatan untuk terlaksananya pembelajaran secara daring.

Oleh sebab itu, dengan mengembangkan LKPD berbasis STEM berteknologi Augmented Reality ini harapannya dapat membantu dalam proses pembelajaran secara daring yang sedang dijalani. Sehingga dapat membuat proses pembelajaran yang lebih interaktif dan berfikir kreatif dalam pelaksanaannya.

Sesuai paparan tersebut, maka dikembangkanlah suatu LKPD yang inovatif untuk masa pandemi yaitu LKPD Arthropoda berbasis STEM berteknologi Augmented Reality. Tujuan dari riset kali ini adalah untuk mengembangkan LKPD Arthropoda berbasis STEM berbantuan teknologi Augmented Reality yang valid berdasarkan uji validitas oleh para ahli.

\section{METODE PENELITIAN}

Penelitian ini merupakan penelitian pengembangan atau R\&D, yaitu metode penelitian yang digunakan untik menghasilkan suatu produk (Sugiyono, 2010). Prosedur penelitian yang dikembangkan ini mengacu pada model ADDIE (Analysis, design, Development, implementation and Evaluating).

Uji validasi LKPD berteknologi Augmented Reality ini dilakukan oleh validator yang berkompeten pada bidangnya, yaitu ahli media dan ahli materi. Teknik analisis 
data yang digunakan pada penelitian ini yaitu desktiptif dengan menghitung dari nilai presentase hasil validasi. Adapun rumus penilaian presentase sebagai berikut:

$$
\text { Persentase }=\frac{\text { Skor Diperoleh }}{\text { Skor Maksimum }} \times 100 \%
$$

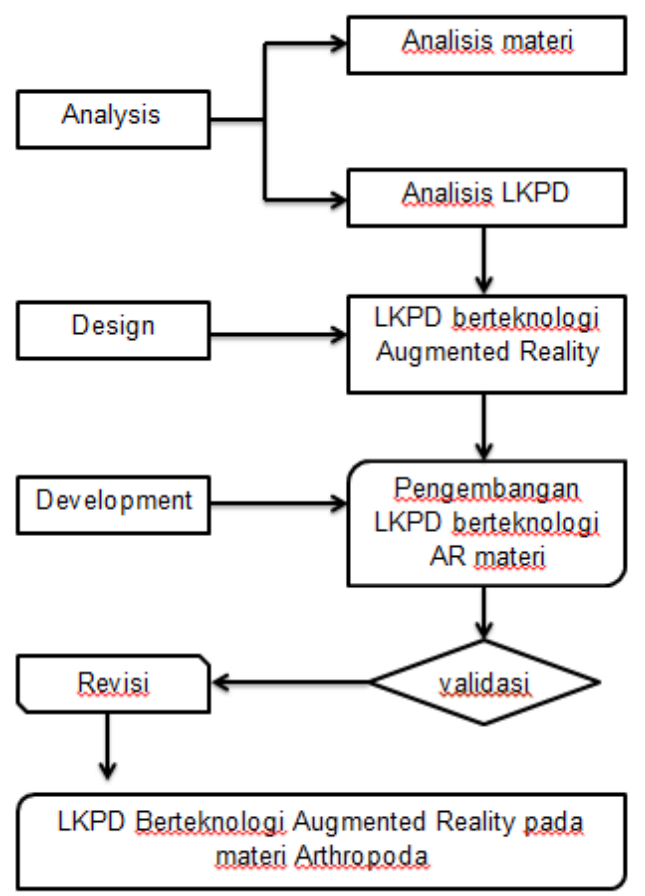

Gambar. 1 Tahap pengembangan LKPD berdasarkan model ADDIE yang termodifikasi

LKPD yang telah divalidasi oleh para ahli kemudian diidentifikasi dengan presentasi skor. Kriteria skor analisis tersebut mengacu pada Riduwan, (2012)

Tabel. 1 kriteria kelayakan analsisi presentase

\begin{tabular}{cl}
\hline Presentase & Keterangan \\
\hline $80-100$ & Baik/valid/layak \\
$60-79$ & Cuku baik/cukup valid/cukup layak \\
$50-59$ & Kurang baik/kurang valid//kurang layak \\
$0-49$ & Tidak baik (ganti) \\
\hline
\end{tabular}

\section{HASIL PENELITIAN DAN PEMBAHASAN}

Hasil penelitian ini merupakan produk pengembangan LKPD (lembar kerja peserta didik) dengan materi Arthropoda berbasis STEM berteknologi Augmented Reality. Penelitian ini merupakan penelitian pengembangan atau R\&D dengan model yang digunakan yaitu mengacu pada ADDIE.

Adapun model rancangan ADDIE, yaitu model dengan 5 tahap yaitu; Analysis (analisis), design (desain), development (pengembangan), implementation (implementasi) dan evaluation (evaluasi). Namun untuk pengembangan LKPD ini tahap ADDIE dimodifikasi sampai pada tahap development (pengembangan), hal ini dikarenakan tujuan dari penelitian ini yaitu sampai pada mengembangkan dan 
menghasilkan suatu LKPD yang valid untuk diimplementasikan kemudian berdasarkan penilaian validator.

Tahapan-tahapan yang telah dilakukan untuk mengembangkan LKPD ini yaitu, analisis. Pada tahap analisis ini yaitu menganalisis kebutuhan siswa ketika observasi dan wawancara dengan menggunakan angket sederhana. Tujuan dilakukan analisis kebutuhan ini merupakan pijakan untuk melakukan pengembangan produk. Seperti menurut Mulyatiningsih, (2011) bahwa analisis dilakukan bisa melalui studi literature atau penelitian pendahuluan. Pada saat analisis kebutuhan didapatkan hasil bahwa semua siswa memiliki smartphone. Sehingga untuk mengembangkan suatu produk dengan media smartphone ada sekolah menengah atas (SMA) tidak sulit untuk diimplementasikan.

Selanjutnya tahap kedua yaitu design atau desain, pada tahap ini dilakukan desain LKPD yang berbasis STEM dengan menyesuaikan angket kebutuhan yaitu perangkat yang digunakan berteknologi Augmented Reality dari smartphone.

Tahap lanjutan dari desain yaitu development atau pengembangan. Dari rangkaian desain tersebut maka dibuatlah suatu LKPD berbasis STEM dengan bantuan teknologi Augmented Reality (AR). Hasil pengembangan yang dibuat yaitu perangkat aplikasi berteknologi AR dan LKPD berbasis STEM. Sehingga untuk menggunakan LKPD ini harus didukung oleh aplikasi AR tersebut.

Adapun LKPD yang dikembangkan sebagai berikut:
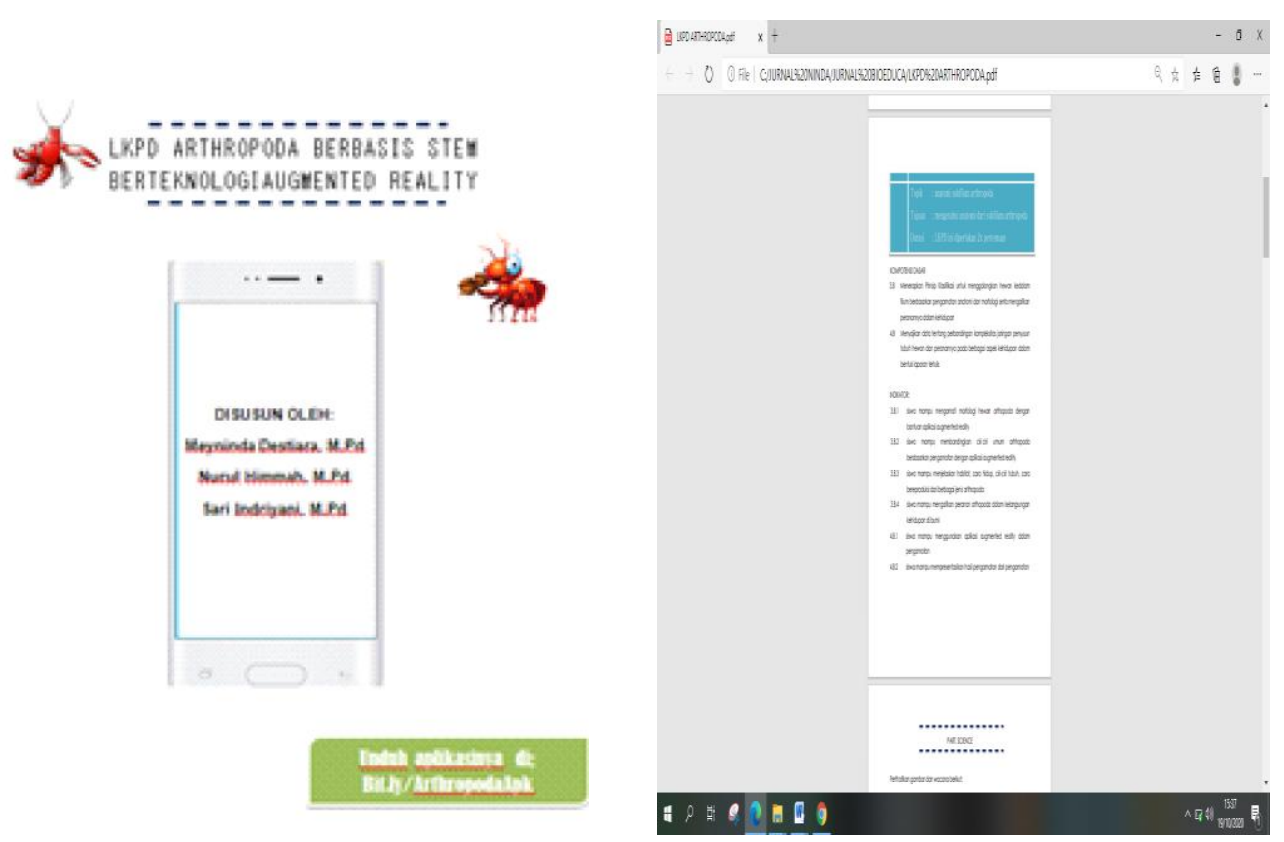

Gambar. 2 Tampilan cover LKPD dan kompetisi dasar yang ingin dicapai

Gambar tersebut merupakan tampilan depan LKPD dan tampilan pada bagian kompetisi dasar yang ingin dicapai. Pada bagian LKPD ini dimodifikasi pada bagian indikator dengan menyesuiakan harapan dari pembuat untuk mencapai tujuan pembelajaran. Sesuai menurut Prastowo (2015) bahwa salah satu fungsi dari LKPD tersebut adalah untuk memudahkan pengajaran kepada peserta didik. Widjajanti (2008) juga menjelaskan bahwa fungsi LKPD yaitu untuk membangkitkan minat 
peserta didik jika LKPD yang disusun dibuat secara rapi, sistematis mudah dipamahi. Oleh sebab itu sesuai dengan harapan kedepannya pemanfaatan LKPD ini untuk memudahkan dan membantu dalam proses pembelajaran daring agar lebih aktif, interaktif dan menarik. Hal ini sesuai dengan tujuan pembelajaran STEM yang dapat membuat siswa menjadi lebih berfikir kreatif dan aplikasi pendukung yang dapat membuat siswa lebih termotivasi karena menarik.
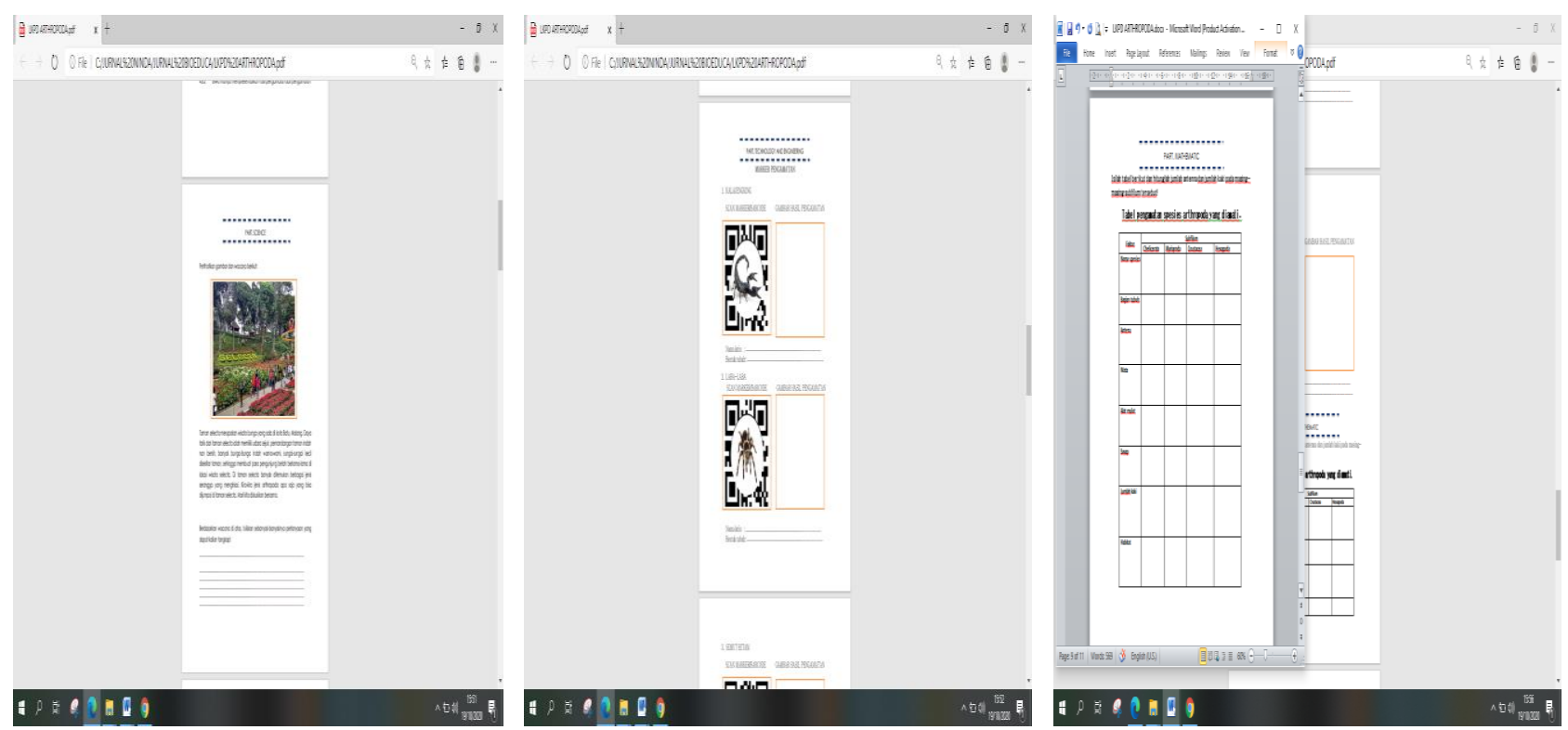

Gambar. 3 rangkaian STEM pada LKPD

Berdasarkan gambar di atas terlihat rangkaian STEM yang disusun untuk mencapai tujuan pembelajaran. Bagian STEM yang terlihat yaitu Sains, yang disusun dengan menampilkan wacana untuk membangkitkan berpikir kritis siswa. Kemudian bagian teknologi dan engineering terdapat marker atau barcode yang dapat digunakan untuk menggunakan aplikasi, oleh sebab itu pada bagian teknologi menggunakan apliasi ini berkaitan dengan engineering yang menggunakan aplikasi pendukung. Pada bagian terakhir yaitu mathematic merupakan bagian menghitung, dibagian ini siswa diarahkan untuk menghitung berapa jumlah antenna, jumlah kaki,yang dilihat pada saat pengamatan dengan menggunakan aplikasi Augmented Reality.

Sesuai menurut Mustqim (2017) bahwa pembelajaran dengan menggunakan teknologi Augmneted Reality dapat menjadikan pembelajaran lebih interaktif. Seiring dengan penelitian oleh Pramuji, dkk (2018) tentang pembelajaran berbasis STEM dapat menciptakan pembelajaran yang mampu meningkatkan kemampuan berpikir kritis siswa. Sehingga ketika digabungkan antara STEM dan teknologi Augmented Reality akan menghasilkan suatu produk yang menarik dan membantu siswa dalam melakukan eksperimen yang dapat membuat pembelajaran benar-benar berjalan sesuai tujuan yaitu lebih interaktif, berpikir kritis dan inovatif.

Hasil pengamatan menggunakan LKPD berbantuan Teknologi Augmented Reality dapat dilihat pada gambar 4 . Sehingga ketika melakukan pengamatan siswa tidak harus memegang spesies yang berbahaya seperti kalajengking, namun bisa dilakukan dengan alternatif pengamatan secara langsung dengan menggunakan 
media berbantuan teknologi Augmented Reality tersebut. Meskipun pada hakikatnya pengamatan langsung tetap harus dilaksanakan karena sesuai kaidah ilmiah bahwa pengamatan ilmiah itu harus secara real-time.

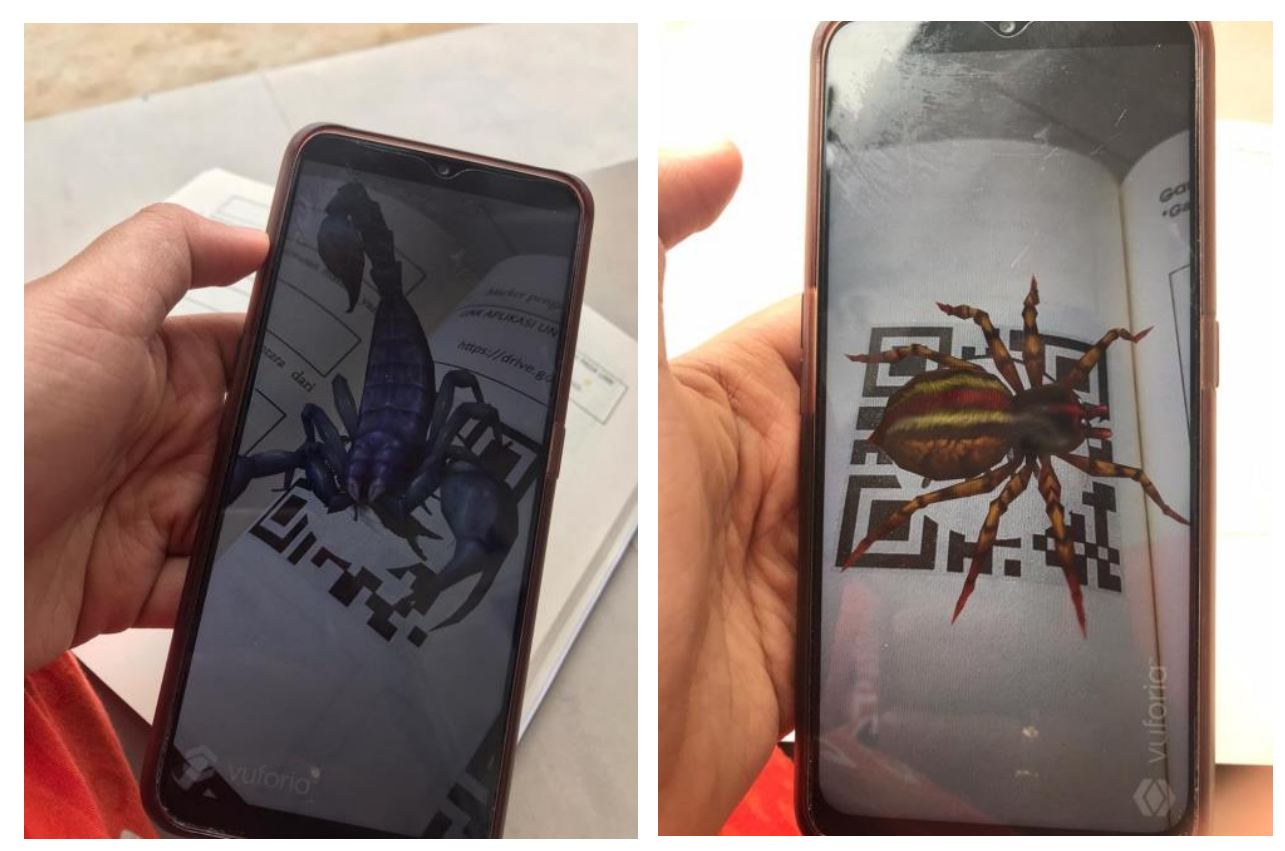

Gambar. 4 tampilan pengamatan LKPD dengan teknologi Augmented Reality

Adapun hasil validasi dari ahli media sebagai berikut:

Tabel.2 hasil validasi ahli media

\begin{tabular}{cc}
\hline Aspek & Presentase \\
\hline Teknik penyajian & $83,3 \%$ \\
Penyajian materi & $82,1 \%$ \\
Kegrafikan & $87,5 \%$ \\
\hline Rata-rata & $84,3 \%$ \\
\hline
\end{tabular}

Sesuai hasil validasi dari ahli media tersebut, didapatkan hasil bahwa LKPD yang digunakan memiliki presentase sebesar $84,3 \%$ dengan predikat valid atau layak digunakan. Selain itu saran dari validator juga sudah layak untuk dikembangkan dengan beberapa revisi sesuai saran. Setelah validasi ahli media maka dilakukan validasi berikutnya yaitu ahli materi. Adapun hasil validasi dari ahli materi sebagai berikut:

Tabel. 3 hasil validasi ahli materi

\begin{tabular}{cc}
\hline Aspek & Presentase \\
\hline Cakupan Materi & $87,5 \%$ \\
Scientific Approach & $83,3 \%$ \\
Kebahasaan & $93,7 \%$ \\
\hline Rata-rata & $88,2 \%$ \\
\hline
\end{tabular}

Sesuai hasil validasi dari ahli materi tersebut maka didapatkan hasil bahwa LKPD yang dikembangkan memiliki presentase sebesar $88,2 \%$ dengan predikat valid atau layak digunaan. Setelah itu juga didapatkan beberapa saran dari validator, oleh sebab itu LKPD ini merupakan produk yang layak digunakan namun harus dilakukan revisi 
guna untuk mencapai LKPD yang lebih baik. Sesuai menurut Destiara dkk (2018) Revisi dilakukan untuk mempertimbangkan hasil validasi serta saran dari validator untuk tercapainya kesempurnaan produk.

Fungsi dari revisi produk merupakan untuk memenuhi standar atas penilaian para ahli terkait LKPD yang dikembangkan, sehingga ketika dilaksanakan uji coba selanjutnya akan mendapatkan hasil yang praktis dalam penggunaannya. Seperti pengembangan buku ajar yang dilakukan oleh Destiara (2020) terkait kepraktisasn pengambangan bahan ajar biologi berbasis islam-sains berbantuan media Augmented Reality, didapatkan presentase tinggi dengan nilai $8,8 \%$ dari uji keterbacaan. Sehingga dari hal tersebut membuktikan bahwa belajar dengan menggunakan media Augmented Reality dapat menambah minat siswa dalam belajar khususnya belajar biologi.

\section{SIMPULAN DAN SARAN}

Berdasarkan dari produk pengembangan tersebut maka didapatkan kesimpulan bahwa produk yang dihasilkan berupa LKPD Arthropoda berbasis STEM berteknologi Augmented Reality yang valid berdasarkan hasil validasi dari para ahli.

\section{UCAPAN TERIMA KASIH}

Terimakasih diucapakan untuk para validator yang telah membantu menuju kesempurnaan produk serta bapak Faisal Rizaldy yang telah membantu kelancaran dalam penyusunan jurnal ini .

\section{RUJUKAN}

Asri (Adinda), Gita Kinanthi Purnama. (2019). Pemanfaatan Smartphone Sebagai Media Pembelajaran Mata Kuliah Koreografi dan Komposisi Tari I. Lentera: Jurnal Ilmiah Kependidikan. Vol. 14 No. 2

Destiara, M, Soendjoto M.A \& Dharmono. (2018). Validitas Bahan ajar jenis ikan di sungai panjaratan pada konsep vertebrata SMA kelas $X$. jurnal inovasi pendidikan sains. Vol. 9 no. 1

Destiara Meyninda \& Hermawan Aldi. Teknologi Augmented Reality sebagai media pembelajran biologi. Jurnal Sistem Informasi dan Bisnis Cerdas (SIBC) vol.13 no.2

Destiara, Meyninda. (2020). The Practicality of Teaching Material Biology of IslamicScience Based on Augmented Reality. Bio-Inoved: Jurnal Biologi-Inovasi Pendidikan. Vol. 2 No. 2

Kemendikbud. (2013). Permendikbud Nomor 65 Tahun 2013 Tentang Standar Proses. Jakarta: Kemendikbud

Kemendikbud. (2020). Permendikbud Nomor 15 Tahun 2020 Tentang Pedoman Penyelenggaraan Belajar dari Rumah dalam Masa Darurat Penyebaran Covid19. Jakarta: Kemendikbud

Kitchenham, A. (2011). Models for interdiscriplinary mobile learning: delivering information to students. Hersey PA: IGI Global.

Laurillard, D.Rethinking university teaching: a framework for the effective use of educational technology (London:Routledge) 
Mulyani Tri. (2019). Pendekatan Pembelajaran STEM untuk Menghadapi Revolusi. Seminar Nasional Pascasarjana 2019. Prosiding. Universitas Negeri Semarang. Mulyatiningsih, E. (2011). Metode Penelitian Terapan Bidang Pendidikan. Yogyakarta: Alfabeta

Mustaqim, Ilmawan. (2017). Pengembangan Media Pembelajaran Berbasis Augmented Reality. Jurnal Edukasi Elektro. Vol. 1 No. 1

Pramuji Lili, Anna Permanasari, Didit Ardianto. (2018). Multimedia Interaktif Berbasis STEM pada konsep Pencemaran Lingkungan Untuk Meningkatkan Kemampuan Berpikir Kritis Siswa. Jurnal of Science Education and Practice. Vol. 2 No.1

Prastowo, Andi. (2015). Panduan Kreatif Membuat Bahan Ajar Inovatif. Yogyakarta: Diva Press.

Riduwan. (2012). Metode \& Teknik Menyusun Proposal Penelitian. Bandung: Alfabeta Suhendra, Hendra. (2020). Pemanfaatan Smartphone Sebagai Media Pembelajaran Berbasis Dasring Pada Masa Covid-19 Di MI Ma'arif 07 Karangmangu Kecamatan Kroya Kabupaten Cilacap. Masters thesis. IAIN Purwokerto. Tidak dipublikasikan

Sugiyono. (2010). Metode Penelitian pendidikan pendekatan kualitatif, kuantitatif dan $R \& D$. Bandung: Alfabeta

Widjajanti, Endang. (2008). Kualitas Lembar Kerja Siswa. (online) (staff.uny.ac.id/system/files/pengabdian/ending../kualitas-Iks.pdf. diakses pada tanggal 18 Oktober 2020) 